\title{
Quantification of Groundwater Resources using Water Table Fluctuation Method in Tirupati Division, Andhra Pradesh State, India
}

\author{
Shanmukha Srinivas Gorantla ${ }^{1,}$,, Yaswanth Kumar Yadiki ${ }^{2}$, Jyothi Pandla ${ }^{3}$ \\ ${ }^{1}$ Department of Civil Engineering, Sri Venkateswara University College of Engineering, Tirupati, Andhra Pradesh, India \\ ${ }^{2}$ Department of Civil Engineering, Gonampalli Pulla Reddy Engineering College, Kurnool, Andhra Pradesh, India \\ ${ }^{3}$ Water Resources Department, Government of Andhra Pradesh, Tirupati, India

\section{Email address:} \\ gssmtech@gmail.com (S. S. Gorantla), yaswanthk2059@gmail.com (Y. K. Yadiki), gsp61433@gmail.com (J. Pandla) \\ ${ }^{*}$ Corresponding author
}

\section{To cite this article:}

Shanmukha Srinivas Gorantla, Yaswanth Kumar Yadiki, Jyothi Pandla. Quantification of Groundwater Resources using Water Table Fluctuation Method in Tirupati Division, Andhra Pradesh State, India. American Journal of Water Science and Engineering. Vol. 6, No. 2, 2020, pp. 65-69. doi: 10.11648/j.ajwse.20200602.12

Received: April 12, 2020; Accepted: April 24, 2020; Published: May 15, 2020

\begin{abstract}
The weathered and fractured zones of hard rock formations constitute the potential aquifers for groundwater development. In India it has been the practice from historical times, to utilize groundwater for either domestic or agricultural purposes mostly through large diameter open wells piercing the shallow weathered portions. There has been an accelerated usage of groundwater during recent times, particularly during the 'Green Revolution'. Due to the advent of modern techniques, simplicity in the construction of bore wells and viability to reach deeper fractured aquifers, the practice of construction of open-dug wells has almost been replaced by drilling of bore wells. The advantage of quick drilling techniques has encouraged many a user to drill to greater depths in the hope of getting higher yields. The net result of indiscriminate drilling is decline of water levels to alarming levels, which results in decrease in well yields and groundwater quality deterioration. It is in this context that an analysis of well yields, variations in static water levels, total depths in these wells of Tirupati revenue division is attempted to understand the well behavior because of the influx of floating as well as resident population is enormously increasing, thereby creating more demand for groundwater. The knowledge about the well yields and characteristics is considered imperative for effective planning and management of groundwater resources in this area. Considering the economic viability, various measures are suggested.
\end{abstract}

Keywords: Groundwater, Water Table, Specific Yield, Well Recharge

\section{Introduction}

Water has been, is, and will be the most important resource of mankind. Most of the cities and towns are built on the banks of rivers or some water bodies. The importance of sustainable water resource management was highlighted in various world conferences to propagate the message on the integrated water resource management. Throughout the world, the people depend on the groundwater resource to meet their water requirements because groundwater is relatively pure with respect to surface water. Therefore, it is necessary to understand the dynamics of groundwater so that the fresh groundwater source could be properly monitored and managed.
Recharge has been defined as "the entry into the saturated zone of water made available at the water-table surface, together with the associated flow away from the water table within the saturated zone" [1]. Groundwater recharge is a key component in any model of groundwater flow or contaminant transport. Accurate quantification of recharge rates is imperative to proper management and protection of valuable groundwater resources. A multiple of methods has been used to estimate recharge. These methods produce estimates over various time and space scales and encompass a wide range of complexity and expense. Unfortunately, given the current state of the science, it is extremely difficult to assess the accuracy of any method. For this reason, it is highly beneficial to apply 
multiple methods of estimation and hope for some consistency in results - even though consistency, by itself, should not be taken as an indication of accuracy. Techniques based on groundwater levels are among the most widely-applied methods for estimating recharge rates. This is likely due to the abundance of available groundwater-level data and the simplicity of estimating recharge rates from temporal fluctuations or spatial patterns of groundwater levels.

This work reviews methods for estimating groundwater recharge that are based on knowledge of groundwater levels. Most of the discussion is devoted to the use of fluctuations in groundwater levels over time to estimate recharge. This approach is termed the water-table fluctuation (WTF) method and is applicable only to unconfined aquifers. In addition to monitoring of water levels in one or more wells or piezometric stations, an estimate of specific yield is required. Other methods, addressed in less detail, include an approach developed by Theis [9] that is based on Darcy's equation and requires knowledge of hydraulic conductivity and hydraulic gradient; Hantush's [5] method for estimating inter aquifer flow; a method derived from an analytical solution of the Boussinesq equation; and an approach that uses transform models and requires precipitation data. Mechanisms that cause water-level fluctuations in unconfined aquifers are closely examined as per Groundwater Estimation Committee (GEC) -1997 recommendations [3].

\section{Study Area}

The sub-continent of India lies in South Asia, of which Andhra Pradesh is a state and Chittoor District of Andhra Pradesh is constituted and the global situation is between $12^{\circ} 37^{\prime}$ to $14^{\circ} 8^{\prime}$ of Northern latitude and $78^{\circ} 33^{\prime}$ to $79^{\circ} 55^{\prime}$ of Eastern longitude. The district is divided in to three revenue divisions viz., Chittoor, Madanapalle and Tirupati with 66 Mandals covering 1540 Revenue Villages. Mandal wise soil texture details are provided for Tirupati revenue division in Table 1.

Table 1. Mandal wise soil type encountered in the study area.

\begin{tabular}{llll}
\hline Mandal No. & Mandal Name & Type of Soil & Specific yield \\
\hline 1 & B. N. Kandriga & Sandy loam & 0.23 \\
2 & Chandragiri & Sandy loam & 0.23 \\
3 & Panapakam & Red soil & 0.23 \\
4 & Chiyyavaram & Sandy loam & 0.23 \\
5 & Empedu & Sandy loam & 0.27 \\
6 & Mamanduru & Red soil & 0.27 \\
7 & Nagalapuram & Red soil & 0.27 \\
8 & Papanaidupet & Sandy loam & 0.27 \\
9 & Pitchatur & Red soil & 0.27 \\
10 & Pulicherla & Red soil & 0.27 \\
11 & Ragigunta & Red soil & 0.23 \\
12 & Satyavedu & Sandy loam & 0.23 \\
13 & Tirupati & Sandy loam & 0.23 \\
14 & Varadaiahpalem & Sandy loam & 0.23 \\
\hline
\end{tabular}

The geology of the rock formations in the state can be classified in to three distinct categories namely hard rocks, soft rocks, and alluvial formations. Groundwater in these rocks occurs under semi-confined or confined conditions. Groundwater is present in secondary porosity of the hard rock's limited to the weathered and fractured zones; joints and bleeding planes etc., in the soft rocks and alluvium, the intergranullar porosity contributes towards occurrence and movement of groundwater. These fractured systems mentioned above are not evenly distributed and have limited aerial and depth extent. Rainfall is the chief source of recharge to groundwater and during the last decade this source has become erratic and sometimes very low. Apart from this people are resorting to use groundwater more often. Thus the strain on groundwater aquifers mostly in upland areas is increasing alarmingly.

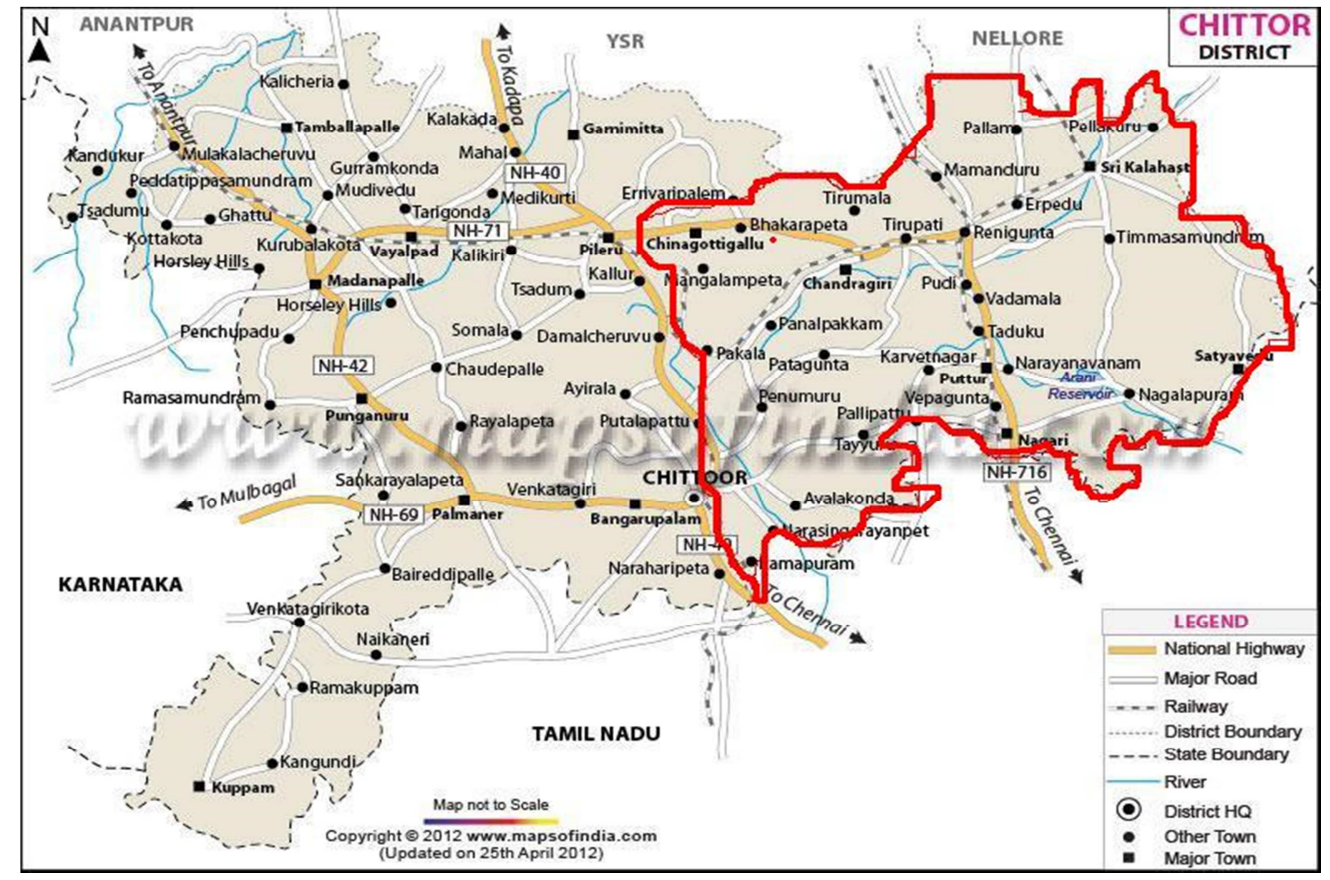

Figure 1. Chittoor District Map Showing Tirupati Revenue Division. 
The average rainfall of the district is $918 \mathrm{~mm}$ it is distributed among the seasons, as in South - West monsoon it is $427 \mathrm{~mm}$, in North - East monsoon it is 391. The above figure shows the study area boundary of Tirupati revenue division covering 14 Mandals with in the Chittoor district of Andhra Pradesh (Figure 1). Deficiency and uneven distribution of rainfall lead to delayed sowings and crop failure in the district. Forty five percent rainfall is received during North-East monsoon which is very important for filling up of tanks and recharging of wells and tube wells. This will be utilized for taking paddy crop in the eastern parts of the district. The crop coverage under tanks, wells and tube wells are directly related to the quantum of rainfall received during Kharif and Rabi seasons. The data was collected from the piezometric observation wells from fourteen mandals of Tirupati revenue division during post monsoon season of year 2019 and recuperation test was conducted at all fourteen locations.

\section{Methodology}

In general the methods used for estimating natural ground water recharge are Soil water balance method, Inverse modelling technique, Water Level Fluctuation (WTF) method, Hybrid water fluctuation method, Ground water balance method and Statistical method. Estimating the rate of aquifer yield is probably the most difficult of all measures in the evaluation of ground water resources.

\subsection{Water-Table Fluctuation Method}

As background, consider the groundwater budget for a basin. Changes in subsurface water storage can be attributed to recharge and groundwater flow into the basin minus base flow (groundwater discharge to streams or springs), Evapotranspiration from groundwater, and groundwater flow out of the basin [10]. The budget can be written as:

$$
\mathrm{R}=\Delta \mathrm{S}^{\mathrm{gw}}+\mathrm{Q}^{\mathrm{bf}}+\mathrm{ET}^{\mathrm{gw}}+\mathrm{Q}^{\mathrm{gw}}{ }_{\text {off }}{ }^{-} \mathrm{Q}^{\mathrm{gw}}{ }_{\text {on }}
$$

Where $\mathrm{R}$ is recharge, $\Delta \mathrm{Sgw}$ is change in subsurface storage, $\mathrm{Q}^{\mathrm{bf}}$ is base flow, $\mathrm{ET}^{\mathrm{gw}}$ is evapotranspiration from ground water, and $\mathrm{Q}^{\mathrm{gw}}{ }_{\text {off }}-\mathrm{Q}^{\mathrm{gw}}{ }_{\text {on }}$ is net subsurface flow from the study area and includes pumping; all terms are expressed as rates (mm/year). The WTF method is based on the premise that rises in groundwater levels in unconfined aquifers are due to recharge water arriving at the water table. Recharge is calculated as:

$$
\mathrm{R}=\mathrm{S}_{\mathrm{y}} \mathrm{dh} / \mathrm{dt}=\mathrm{S}_{\mathrm{y}} \Delta \mathrm{h} / \Delta \mathrm{t}
$$

Where Sy is specific yield, $h$ is water-table height, and $t$ is time. Derivation of Eq. (2) assumes that water arriving at the water table goes immediately into storage and that all other components of Eq. (1) are zero during the period of recharge. A time lag occurs between the arrival of water during a recharge event and the redistribution of that water to the other components of Eq. (1). If the method is applied during that time lag, all of the water going into recharge can be accounted for. This assumption is mostly valid over short periods of time (hours or a few days), and it is this time frame for which application of the method is most appropriate. The length of the time lag is critical in this method.

For the WTF method to produce a value for total or "gross" recharge requires application of Eq. (2) for each individual water-level rise. Equation (2) can also be applied over longer time intervals (seasonal or annual) to produce an estimate of change in subsurface storage, $\Delta \mathrm{Sgw}$. This value is sometimes referred to as "net" recharge. With some additional assumptions, the WTF method can be used to estimate any of these parameters.

\subsection{Specific Yield $\left(S_{y}\right)$}

The Specific yield $\left(\mathrm{S}_{\mathrm{y}}\right)$ of a soil or rock is the ratio of the volume of water that, after saturation, can be drained by gravity to its own volume. Values of specific yield depend up on grain size, shape and distribution of pores, compaction of the stratum and time of drainage. Representative specific yields for various geological materials are listed in Table 2. Individual values for a soil or rock can vary considerably from these values.

Table 2. Specific yield values for different types of soils.

\begin{tabular}{llll}
\hline Material & $\begin{array}{l}\text { Specific } \\
\text { yield (\%) }\end{array}$ & Material & $\begin{array}{l}\text { Specific } \\
\text { yield (\%) }\end{array}$ \\
\hline Gravel, coarse & 32 & Sandstone & 27 \\
Gravel, medium & 24 & Lime stone & 14 \\
Gravel, fine & 25 & Dune sand & 38 \\
Sand, coarse & 27 & Loess & 18 \\
Sand medium & 28 & Peat & 44 \\
Sand fine & 23 & Schist & 26 \\
Silt & 8 & Siltstone & 12 \\
Clay & 3 & predominantly slit & 6 \\
Sandstone, fine-grained & 21 & & \\
\hline
\end{tabular}

The WTF method for estimating groundwater recharge was applied as early as the 1920s [6] and since then has been used in numerous studies [7, 2, 4]. The attractiveness of the WTF method lies in its simplicity and ease of use. No assumptions are made on the mechanisms by which water travels through the unsaturated zone; hence, the presence of preferential flow paths within the unsaturated zone in no way restricts its application. Because the water level measured in an observation well is representative of an area of at least several square meters, the WTF method can be viewed as an integrated approach and less a point measurement than those methods that are based on data in the unsaturated zone.

\section{Results and Discussion}

The Water Table Fluctuation (WTF) method is based on the premise that rises in groundwater levels in unconfined aquifers is due to recharge arriving at the water table. 
Recharge is calculated as the change in water level overtime multiplied by specific yield. This approach is a gross simplification of a very complex phenomenon namely movement of water to and from the water table. Favorable aspects of the WTF method include its simplicity and ease of use: it can be applied for any well that taps the water table, and then abundance of available water level data exists. This method requires no assumptions on the mechanisms for water movement through the unsaturated zone. Hence the presence of preferential flow paths does not restrict its use. Recharge rates calculated with the WTF method are values that are integrated over areas of several square meters to hundreds or thousands of square meters.

Table 3. Analysis of Water Table Fluctuation Method.

\begin{tabular}{|c|c|c|c|c|c|c|c|}
\hline S. No & Mandal & Area $\left(\mathrm{km}^{2}\right)$ & Specific yield & Depth of fluctuation & YEILD (MCM) & Cumulative variation (\%) & Remarks \\
\hline 1 & B. N. Kandriga & 217.50 & 0.23 & 10.67 & 533.77 & 63.19 & safe \\
\hline 2 & Chandragiri & 430.00 & 0.23 & 12.70 & 1256.03 & 13.38 & safe \\
\hline 3 & Panapakam & 430.00 & 0.23 & 7.03 & 695.27 & 52.05 & safe \\
\hline 4 & Cheyyavaram & 165.00 & 0.23 & 9.51 & 360.90 & 75.11 & semi critical \\
\hline 5 & Empedu & 262.50 & 0.27 & 4.23 & 299.80 & 79.32 & semi critical \\
\hline 6 & Mamanduru & 375.00 & 0.27 & 5.42 & 548.78 & 62.15 & safe \\
\hline 7 & Nagalapuram & 277.50 & 0.27 & 4.18 & 313.19 & 78.40 & semi critical \\
\hline 8 & Papanaidupet & 262.50 & 0.27 & 12.05 & 854.04 & 41.10 & safe \\
\hline 9 & Pitchatur & 277.50 & 0.27 & 9.29 & 696.05 & 52.00 & safe \\
\hline 10 & Pulicherla & 87.50 & 0.27 & 17.36 & 410.13 & 71.72 & semi critical \\
\hline 11 & Ragigunta & 277.50 & 0.23 & 7.41 & 472.94 & 67.38 & safe \\
\hline 12 & Satyavedu & 252.50 & 0.23 & 6.82 & 396.07 & 72.68 & semi critical \\
\hline 13 & Tirupati & 375.00 & 0.23 & 20.89 & 1801.76 & -24.26 & over exploited \\
\hline
\end{tabular}

Present study revealed that $8865 \mathrm{MCM}$ of yield is obtained from groundwater recharge in the fourteen mandals of Tirupati revenue division with $9.44 \mathrm{~m}$ average fluctuation of groundwater table (Table 3). Wells in the study area should be located so that the water levels they monitor are representative of the aquifer as a whole. WTF method is best applied to systems with shallow water tables that display short rises and declines. Analyses of water level fluctuations can, however, be useful for determining the magnitude of long term changes in recharge caused, perhaps, by changes in climate or land use changes. Time is required for the pressure front from increased deep drainage to move downward through the unsaturated zone. This time delay is related to the recharge date, the soil water content, and the depth to the water table. Presumably the pressure front was still being propagated through the unsaturated zone in areas with deeper water table.

Determining a proper value for specific yield is a difficult endeavor. The values of specific yield determined from laboratory or field test are usually dependent on the amount of time allowed for the test. The WTF method is only capable of estimating recharge when water is arriving at the water table at a greater rate than its leaving, a condition that produces a water level rise. Recharge can still be occurring even when a well hydrograph shows that water levels are declined (Figure 2). Such an occurrence simply indicates that rate of recharge is less than the rate of water movement away from the water table. If water movement away from the water table were equal the steady recharge rate, no change in water level would occur, and WTF method would predict no recharge.
Table 4. Groundwater Resources in Study Area and Classifications.

\begin{tabular}{ll}
\hline Classification according to GEC Norms & No. of Mandals \\
\hline Safe $(<70 \%$ of net available resource) & 07 \\
Semi-critical $(70-90 \%)$ & 06 \\
Critical $(90-100 \%)$ & 00 \\
Over exploited $(>100 \%)$ & 01 \\
TOTAL & 14 \\
\hline
\end{tabular}

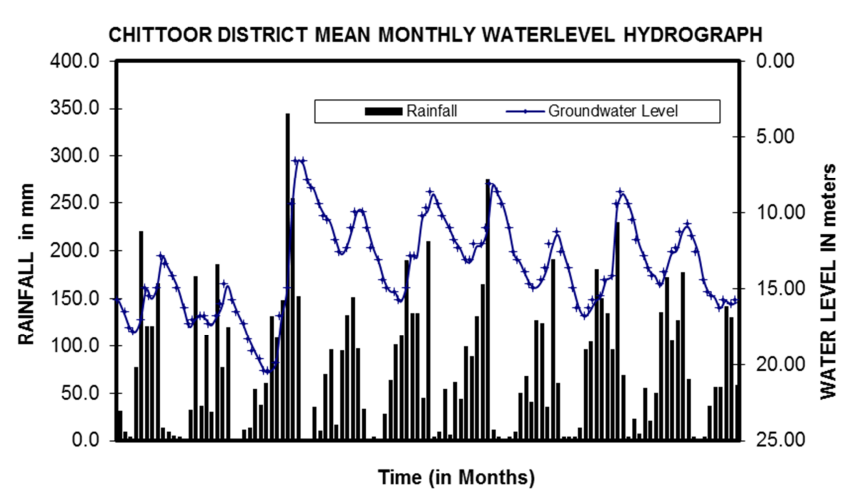

Figure 2. Tirupati Division Mean Monthly Watertable Fluctuation and hydrograph.

From the analysis, all the fourteen mandals were classified as per GEC norms and results revealed that seven mandals are in Safe category, six mandals are in Semi-Critical and the rest Tirupati is over-exploited where remedial measures like constructing rainwater harvesting structures and application of artificial recharge methods to be implemented as shown in Table 4 


\section{Conclusions}

Application of WTF method to fractured rock aquifers offers some peculiar challenges. Fractures usually serve as the primary conduits for water movement, but they account for a small percentage of the total storage available in the aquifer. Therefore care must be exercised in the value of specific yield and in analyzing water level fluctuations. Accurate quantification of recharge rates is imperative to proper management and protection of ground water resources. A major concern in application of the method described in this paper, as well as most other methods for the estimating recharge is difficult in assessing the uncertainty associated with any given estimate. Unfortunately, the hydrogeology discipline has not yet arrival at a point where it is practical. Uncertainties and inaccuracies arise from several sources: spatial and temporal variability in processes and parameter values, measurement errors, and the validity of assumptions up on which different methods are based. The simplicity of estimating recharge rates from information on temporal fluctuations and groundwater levels is attracting.

\section{References}

[1] Freeze RA, cherry JA (1979) Ground water, Prentice-hall, Engle wood Cliffs, NJ, 604 pp.

[2] Gerhart JM (1986) Groundwater recharge and its effect on nitrate concentrations beneath a manured field site in Pennsylvania. Groundwater 24: 483-489.

[3] Groundwater Estimation Committee (GEC) Report - 1997, CGWB, Govt. of India.

[4] Hall DW Risser DW (1993) effects of agricultural nutrient management on nitrogen fate and transporting in Lancaster County, Pennsylvania. Water Resour Bull 29: 55-76.

[5] Hantush MS (1956) Analysis of Data from pumping tests in leaky Aquifers. Trans Am Geophys Union vol 37, no 6.

[6] Meinzer OE (1923) the occurrence of groundwater in the United States with a discussion of principles. US GeolSurv Water-Supply Pap 489, 381 pp.
[7] Rasmussen WC Andreasen GE (1959) Hydrologic Budget of the Beaver dam Creek Basin, Mary land. US Geol Surd WaterSupply Pap 1472: 106 p.

[8] Richard W. Healy. Peter G. cook (2002) Using ground water levels to estimate recharge, Hydrogeology Journal (2002) 10: 91-109.

[9] Theis CV (1937) Amount of groundwater recharge in the Southern High Plains. Trans Am Geophys Union 8: 564-568.

[10] Walton WC (1961) Groundwater resource evaluation. McGraw -Hill, New York, 664 pp.

[11] S. K. Garg, Irrigation Engineering and Hydraulic Structures (Khanna publishers 2-B, Nath Market, Nai Sarak, Delhi110006, 1976).

[12] M. R. Hasan, M. G. Mostafa and I. Matin, Effect of Groundwater Level Fluctuation in Chapai Nawabgonj District, International Journal of Engineering Research \& Technology (IJERT), 2 (4), April 2013, 2800-2807.

[13] Hughes, D. A.; Hannart, P. A desktop model used to provide an initial estimate of the ecological in stream flow requirements of rivers in South Africa. Journal of Hydrology 2003, 270, 167-181.

[14] Tallaksen, L. M.; Van Lanen, H. A. Hydrological drought: processes and estimation methods for streamflow and groundwater; Elsevier, 2004; Vol. 48.

[15] Adelana SMA, Olasehinde P. I and Vrbka P. (2006). A quantitative estimation of groundwater recharge in parts of Sokoto Basin, Nigeria. Journal Environmental Hydrology, 14 (5): 1-17.

[16] Nwankwoala, H. (2015). Hydrogeology and Groundwater Resources of Nigeria. New York Science Journal, 8 (1): 89100.

[17] Hsin-Fu, Y., Cheng-Haw, L., Kuo-Chin, H., Po-Hsun C. (2009). GIS for the assessment of the groundwater recharge potential zone. Environ Geol. 58: 185-195.

[18] Water, U. Integrated Monitoring Guide for Sustainable Development Goal 6 on Water and Sanitation-Targets and global indicators. 2017. 